\title{
Synthesis, Characterization and Anticancer Studies of Fe(II)Cysteinedithiocarbamate Complex
}

\author{
Rizal Irfandi ${ }^{1}$, Prihantono ${ }^{2}$, Indah Raya ${ }^{3}$, Desy Kartina ${ }^{4}$, Riswandi ${ }^{5}$ \\ $1,3,4,5$ Department of Chemistry, Faculty of Mathematics and Natural Science, Universitas \\ Hasanuddin, Makassar, Indonesia. 90245 \\ ${ }^{2}$ Department of Surgery, Faculty of Medical, Universitas Hasanuddin, Makassar, Indonesia. \\ 90245 \\ \{rizalirfandi043@gmail.com¹,prihantono.md@gmail.com²,indahraya05@gmail.com³, \\ desy.kartina@yahoo.com ${ }^{4}$,wandykimia@gmail.com ${ }^{5}$ \}
}

\begin{abstract}
Fe(II)cysteindithiocarbamate complex has been synthesized by an in-situ method. Complex characterized using Ultra Violet Visible (UV-Vis), Infra Red (IR), melting point and molar conductivity. The presence of UV-Vis maximum spectrums of $\mathrm{Fe}(\mathrm{II})$ cysteindithiocarbamate at $245 \mathrm{~nm}$ and $354 \mathrm{~nm}$ indicated that electronic transition $\pi \rightarrow \pi^{*}$ dan $n \rightarrow \pi^{*}$ of $\mathrm{CS}_{2}$ and $\mathrm{N}=\mathrm{C}=\mathrm{S}$. While the presence of IR spectra at the wavelength in the region of $393-540 \mathrm{~cm}^{-1}$ indicated that has been coordination occurred between Fe(II) with Sulphur (S), Nitrogen (N) and Oxygen $(\mathrm{O})$ atoms from cysteinedithiocarbamate ligands. Anticancer activity tests of $\mathrm{Fe}(\mathrm{II})$ complex and metals without ligands on the breast cancer cell line (MCF-7) were carried out in vitro. The results of the cytotoxicity test showed that $\mathrm{Fe}(\mathrm{II})$ complex had the potential as an anticancer for MCF-7 cancer cells compared to metals without ligands which showed a non-toxic effect on cancer cells.
\end{abstract}

Keywords: Complexes, Cysteine, Dithiocarbamate, Apoptosis, MCF-7.

\section{Introduction}

Metal complexes have been widely used in the medical world lately [1-3]. Supported by the coordination of ligands that have the ability of biological activity to attract a lot of attention in recent decades [4]. The success of platinum-based cancer drugs, such as cisplatin, carboplatin, and oxaliplatin, has been shown to be effective and toxic to cancer cells. However, all these platinum-based drugs have side effects and drug resistance during the therapeutic process, this makes inorganic chemists look for and develop more effective and less toxic metal-based anticancer drugs $[1,5,6]$. In general metal complexes with DNA are covalently coordinated with a variety of specific geometric forms [7]. Besides that, metal complexes can also be intercalated into the gap between the pair of double helix DNA bases. However, most of these reactions occur in complexes containing planar aromatic heterocyclic ligands $[8,10]$. The research and study of cancer drugs from complex compounds using essential metals that are able to interact with nucleic acids and trigger current apoptosis is one of the most promising strategies for researchers in finding anticancer drugs with target DNA [11-13].

Transition metal complexes such as Fe(II) are complexes that are in great demand and are of concern to many researchers in order to develop the discovery of effective and non-toxic 
metal-based cancer drugs. Besides that, iron also plays an important role in physiological processes and has many known functions in biochemical processes. The stability of the complexes formed and their solubility in water coupled with their specific spectroscopic properties are very suitable as compound models for study purposes in biological systems [14]. $\mathrm{Fe}(\mathrm{II})$ complex with amine dithiocarbamate ligand is still rarely studied.

The biological properties of ligands have a significant influence on the activity of complex compounds in the development of cancer drugs [15]. Dithiocarbamate is known to be very potent in the world of medicine. The use of the dithiocarbamate compound depends on the chelating properties of the dithiocarbamate ligand against metal ions. In the health field, the dithiocarbamate compound can be a metal-based drug poisoning which acts as a good chelating agent [16]. In addition, this compound can also be used as a radio chemotherapy target agent in tumors [17].

\section{Material and Methods}

Iron Chloride $\left(\mathrm{FeCl}_{2}\right)$, Cysteine, Ethanol (95\%) Methanol (95\%), Acetone (95\%), n-hexane (95\%), Acetonitrile (95\%), Carbon disulphide, Cisplatin, Roswell Park Memorial Institute Medium,. Phosphate buffered saline (PBS), PrestoBlue ${ }^{\mathrm{TM}}$ Cell Viability Reagent, Trypsin-EDTA, Trypan Blue and DMSO (chemicals and solvents were obtained from Merck).

\subsection{Synthesis of cysteinedithiocarbamate ligand}

Cysteine $0.6133 \mathrm{gr}(5 \mathrm{mmol})$ was dissolved in $10 \mathrm{~mL}$ ethanol and $\mathrm{CS}_{2} 0,3 \mathrm{~mL}(5 \mathrm{mmol})$ was added to the $10 \mathrm{~mL}$ ethanol solution under conditions under $10^{\circ} \mathrm{C}$ and stirred for 10 minutes. 


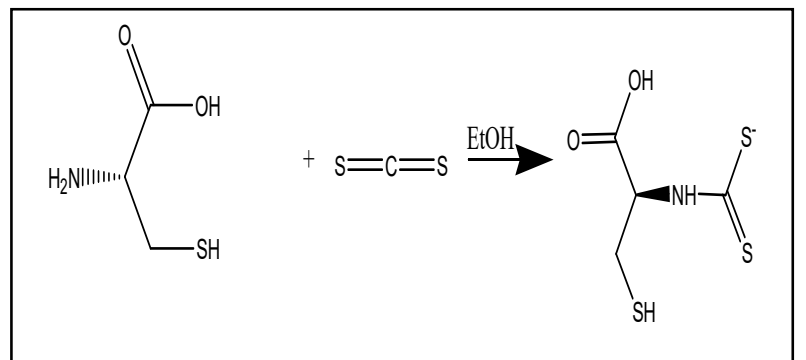

Fig. 1. Synthesis reaction of cysteinedithiocarbamate ligand

\subsection{Synthesis of $\mathrm{Fe}(\mathrm{II})$ with cysteinedithiocarbamate ligand}

The cysteinedithiocarbamate ligand solution was added $\mathrm{FeCl}_{2} 0.3802 \mathrm{gr}(3 \mathrm{mmol})$, which was dissolved in $10 \mathrm{~mL}$ ethanol and stirred for 30 minutes. Then the precipitate formed is then filtered and washed with ethanol and dried in a desiccator after recrystallization with the appropriate solvent, the mixture of acetonitrile and ethanol $(1: 2 . \mathrm{v} / \mathrm{v})$, and the characterization of the product.

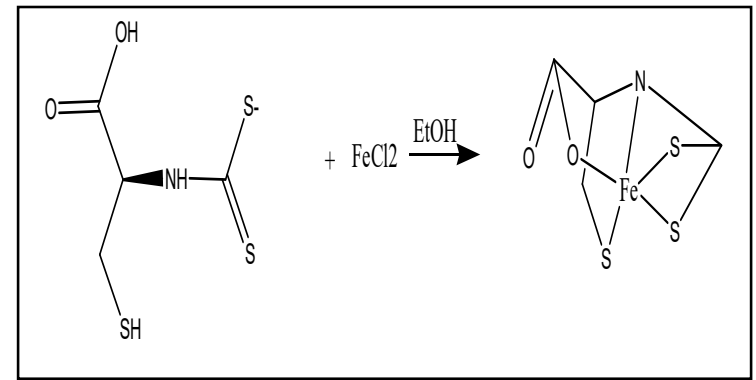

Fig. 2. Synthesis reaction of Fe(II)cysteinedithiocarbamate

\subsection{Characterization of Complex}

The electronic spectra obtaining by using UV-Vis Jenwey spectrophotometer 200-1100 nm and Infra Red spectra perform by using Infra Red SHIMADZU spectrophotometer, in 4000-300 $\mathrm{cm}^{-1}$ range of frequency. Melting point was measured with Electrothermal IA 9100, and conductivity was measured with conductometer.

\subsection{The Cytotoxic Assay of MCF-7 Breast Cancer Cells}

The MCF-7 cell cultures were placed into 96 well plates and then incubated at $37^{\circ} \mathrm{C}$ and $5 \%$ of $\mathrm{CO}_{2}$ gas until the percentage of cell growth reaches $70 \%$. Next cells were treated with $\mathrm{Fe}(\mathrm{II})$ cysteindithiocarbamate complexes and then incubated (for 48 hours at $37^{\circ} \mathrm{C}$ and $5 \% \mathrm{CO}_{2}$ gas). To facilitate reading of absorbance, it was adding a presto blue work reagents on to the cell. Absorbance measured by using Multimode Reader. 


\section{Results and Discussion}

The result of the synthesis of $\mathrm{Fe}(\mathrm{II})$ cysteindithiocarbamate complex was $36.19 \%$. The melting point obtained is $240^{\circ} \mathrm{C}-242^{\circ} \mathrm{C}$, which shows strong complex stability and conductivity values obtained at $0.05 \mathrm{mS} / \mathrm{cm}$, which indicates that the complex was non electrolyte.

\subsection{UV-Vis characterization}

The results of characterization with UV-Vis in water solvents for complex $\mathrm{Fe}(\mathrm{II})$ cysteinditiocarbamate compounds (Fig.3) obtained in band 1 show absorption bands at wavelength $245 \mathrm{~nm}$ which are intraligand transitions $\pi \rightarrow \pi^{*}$ from $\mathrm{CS}_{2}$ groups which are influenced by the presence of the $\mathrm{R}$ group hyperconjugation to nitrogen atoms in the absorption area of 245-300 nm [18]. The shift in the II band which is an intraligand transition $n \rightarrow \pi^{*}$ from the group $\mathrm{N}=\mathrm{C}=\mathrm{S}$ at wavelengths $354 \mathrm{~nm}$ is indicated by complex compounds.

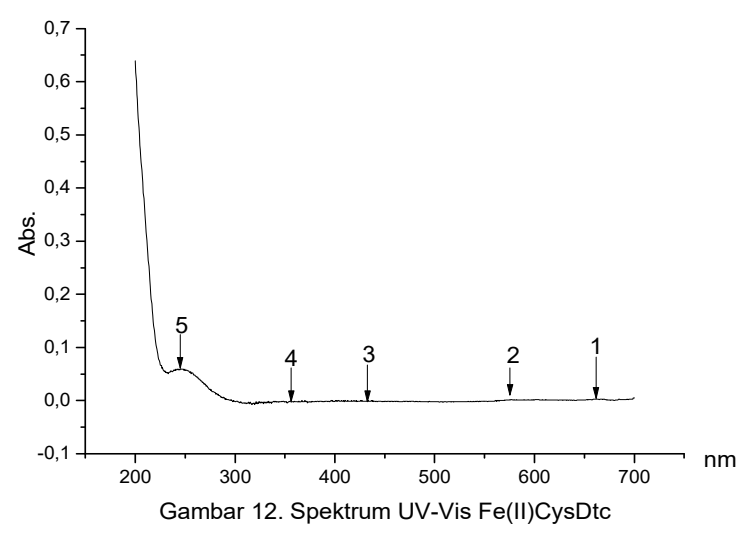

Fig.3. UV-Vis spectrum of Fe(II)cysteinedithiocarbamate

\subsection{IR characterization}

Dithiocarbamate complex compound, for $\mathrm{v}(\mathrm{C}-\mathrm{N})$ lies in the wave number between single bonds (1350-1250) $\mathrm{cm}^{-1}$ and double bonds $(1690-1640) \mathrm{cm}^{-1}$, so the bond is written as $\mathrm{v}(\mathrm{C}=\mathrm{N})$. Furthermore, for $\mathrm{C}-\mathrm{S}$ uptake it is written as $\mathrm{v}(\mathrm{C}=\mathrm{S})$, with the number of wavelengths being between double bond wave numbers $C=S(1050-1200) \mathrm{cm}^{-1}$ and single bonds $C-S(550-800) \mathrm{cm}^{-1}$ [19]. To ascertain the existence of bonds between metals and ligands was observed in far infrared absorption (400-100) $\mathrm{cm}^{-1}$, namely the presence of sulfur metal bond strain from dithiocarbamate ligands and metal bonds with nitrogen from bipyridyl or phenanthroline ligands [20].

Infra Red absorption peak at wave number $393 \mathrm{~cm}^{-1}$ indicates interaction of S atoms with $\mathrm{Fe}(\mathrm{II})$ metal ions. The absorption peak at wave number $455 \mathrm{~cm}^{-1}$ indicates the interaction of $\mathrm{O}$ atoms of complex compounds with $\mathrm{Fe}(\mathrm{II})$ metal ions. The absorption peak at wavenumber 540 $\mathrm{cm}^{-1}$ indicates the interaction of $\mathrm{N}$ atoms of complex compounds with each $\mathrm{Fe}$ (II) metal ions. The appearance of absorption at wavenumber $1109 \mathrm{~cm}^{-1}$ shows a single absorption peak which indicates bidentate coordination between groups $(\mathrm{C}=\mathrm{S})$ with $\mathrm{Fe}(\mathrm{II})$ metal ions. Then there is a strong absorption at the wavenumber $1622 \mathrm{~cm}^{-1}$ which indicates that it is derived from the amine group $(\mathrm{C}=\mathrm{N})$. Results of the spectrum of complex compounds that have been synthesized, Fig. 4. 


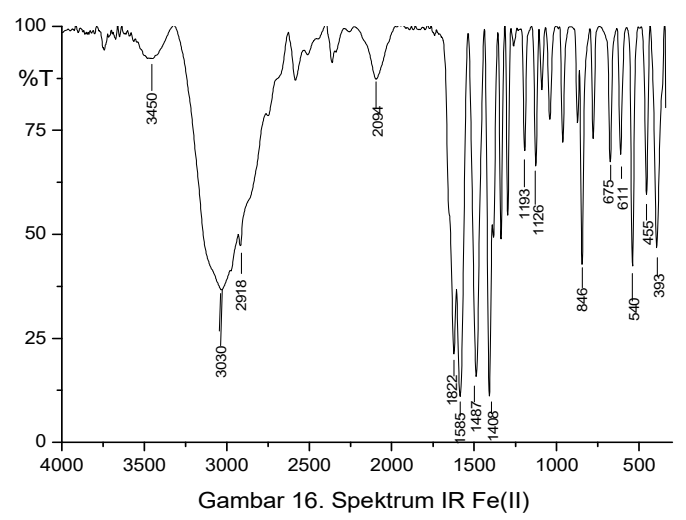

Fig.4. IR spectrum of Fe(II)cysteindithiocarbamamate

\subsection{Cytotoxic Assay of Fe(II) Complex on MCF-7 Cancer Cells}

In vitro cytotoxicity experiments were carried out with the $\mathrm{Fe}$ (II) cysteindithiocarbamate complex against the MCF-7 cancer cell line at 7.81, 15.63, 31.25, 62.50, 125.00, 250.00, 500.00, and $1000.00 \mu \mathrm{mol} / \mathrm{mL}$. Inhibition of the complex effects of Fe (II) cysteindithiocarbamate on the MCF-7 cancer cell line increases with increasing complex concentrations characterized by morphological changes in MCF-7 cancer cells (Fig. 5). Whereas cytotoxicity in Fe(II) metals without ligands showed no morphological changes in MCF-7 cancer cells (Fig.6).

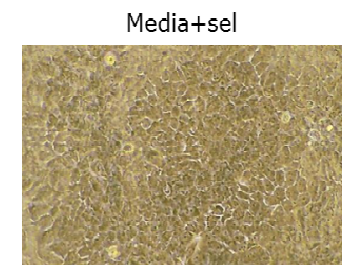

DMSO $3,00 \%$

Cisplatin
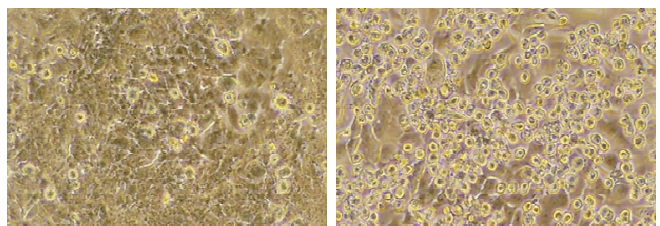

Sampel $1000 \mu \mathrm{g} / \mathrm{mL}$

Sampel $500 \mu \mathrm{g} / \mathrm{mL}$

Sampel $250 \mu \mathrm{g} / \mathrm{mL}$

Sampel $125 \mu \mathrm{g} / \mathrm{mL}$
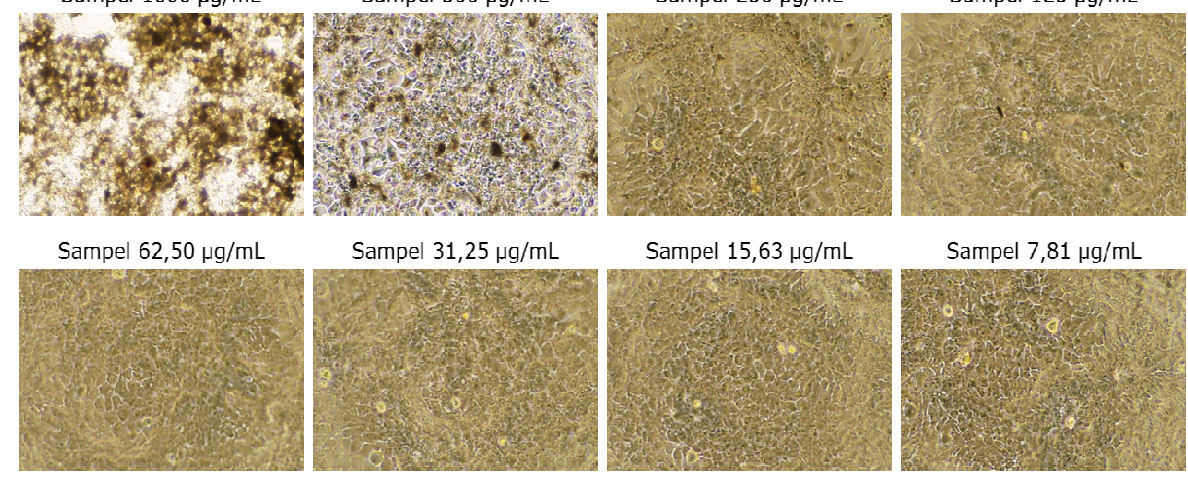

Sampel $31,25 \mu \mathrm{g} / \mathrm{mL}$

Sampel 15,63 $\mathrm{\mu g} / \mathrm{mL}$

Sampel $7,81 \mu \mathrm{g} / \mathrm{mL}$
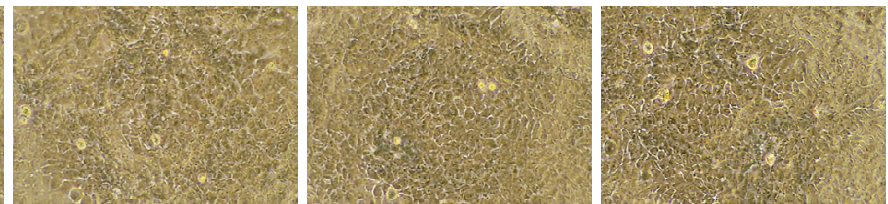
Fig.5. Morphological changes induced by Fe(II)cysteindithiocarbamate in MCF-7 cells

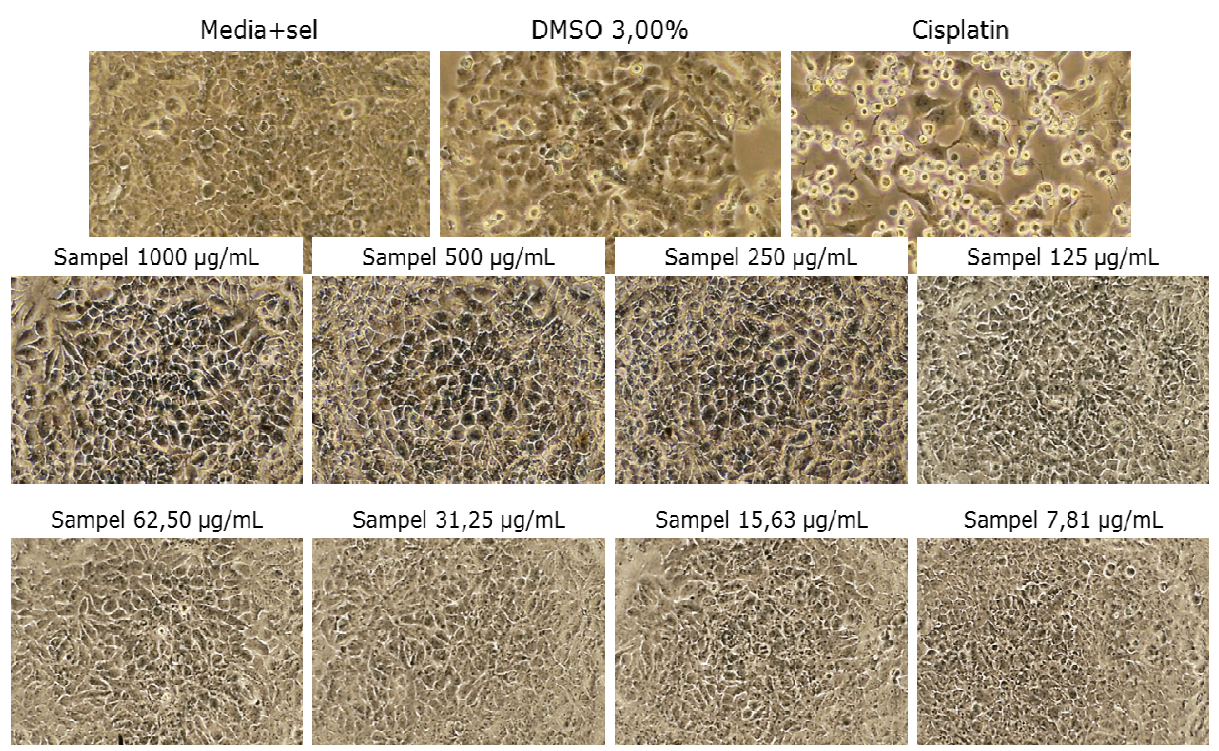

Fig.6. No change in morphological by Fe(II) without ligands in MCF-7 cells

Metal ions from complex compounds can connect the two strands to form intra-strand cross-links, bonding to two DNA strands in a double helix. This intra-strand cross bond prevents cell breakdown through the mitosis process so that the tumor stops growing. Then the tumor cell becomes rigid which is induced by crosslinking on metal ions so that it cannot be recognized and DNA cannot be repaired. As result cells experience death (apoptosis) [21]. Based on the results obtained in this study, it is very clear the influence of ligands in increasing the cytotoxicity of complex compounds against MCF-7 cancer cells. This is evidenced by the differences in morphological changes obtained between metal complexes with metals without ligands. In this process, it is possible to process ligand intercalation into DNA base pairs [22].

\section{Conclusion}

Complex characterization using UV-Vis and IR showed that the complex $\mathrm{Fe}(\mathrm{II})$ cysteindithiocarbamate was synthesized by the in-situ method. The results of the cytotoxicity test on MCF-7 showed that the Fe(II) complex has potential as an anti-cancer drug, which is indicated by the morphological changes of MCF-7 cancer cells. Whereas in metals without ligands showed no change in morphology of cancer cells.

\section{Acknowledgements}

We thank the Inorganic Research Center Laboratory of Hasanuddin University, Makassar, Indonesia for supporting this research. 


\section{References}

[1] Qiao, X., Ying, MZ., Zhi, XC., Xue, F., Zhang, YW., Xu JY., et.al.: Study on potensial antitumor mechanism of a novel Schiff Base copper(II) complex: Synthesis, crystal structure, DNA binding, cytotoxicity and apoptosis induction activity. Journal of Inorganic Biochemistry. Vol. 105, pp. 728-737. Doi: 10.1016/j.jinorgbio.2011.01.004 (2011)

[2] Milacic, D. Chen, L. Ronconi, K.R. Landis-Piwowar, D. Fregona, Q.P. Dou.: A novel anticancer gold(III) dithiocarbamate compound inhibits the activity of a purified $20 \mathrm{~S}$ proteasome and 26S proteasome in human breast cancer cell cultures and xenografts. Cancer Res, 66(21), pp. 10478-86. Doi: 10.1158/0008-5472.CAN-06-3017 (2006)

[3] I. Kostova.: Gold coordination complexes as anticancer agents, Anticancer Agents Med. Chem, 6(1), pp. 19-32. (2006). PubMed PMID: 16475924.

[4] Mokhles, M. Abd-Elzaher., Samin, A. Moustafa., Ammar, A. Labib., Hanan, A. Mousa., Mamdoudh, M. Ali., dan Abeer, E.Mahmoud.: Synthesis, Characterization and Anticancer Studies of Ferrocenyl Complexes Containing Thiazole Moiety. Appl. Organometal. Chem. Vol. 26, pp.230-236. Doi.org/10.1002/aoc.2844 (2012)

[5] D. Chatterjee, A. Mitra, G.S. De. Inorganic/Bioinorganic Reaction Mechanisms, Platinum Met. Rev, 50, pp. 1-275 (2006).

[6] Dorcier, Antoine., Han Ang Wee., Bolano, Sandra., Gonsalvi, Luca., Juillerat-Jeannerat, Lucienne., Laurenczy, Gabor., Peruzzini, Maurizio., D. Philips, Andrew., Zanobini, Fabrizio dan J. Dyson, Paul.: In Vitro Evaluation of Rhodium and Osmium RAPTA Analogues: The Case for Organometallic Anticancer Drugs Not Based on Ruthenium. Organometallic, 25, pp. 4090-4096. Doi.10.1021/om060394o (2006)

[7] Shriver, D.F., Atkins, P.W., Langford, C.H.: Inorganic Chemistry, 4nd ed, Oxford University Press, pp.706. https://trove.nla.gov.au/version/45045927 (1990).

[8] Lerman, L.S.: Structural considerations in the interaction of DNA and acridines, Journal of Molecular Biology, Vol. 3, pp.18-30. Doi:org/10.1016/S0022-2836(61)80004-1 (1961)

[9] P.U. Maheswari, M. Ster, S. Smulders, S. Barends, G.P. Wezel, C. Massera, S. Roy, H. Dulk, P. Gamez, J. Reedijk,: Structure, cytotoxicity, and DNA-cleavage properties of the complex [Cu(II)(pbt)Br2]. Inorg. Chem, 47(9), pp. 19-27. Doi: 10.1021/ic702306f (2008)

[10] Bruijnincx, Pieter CA., and Sadler.: New trends for metal complexes with anticancer activity. Current Opinion in Chemical Biology, Vol. 12, pp. 197-206. Doi: 10.1016/j.cbps.2007.11.013 (2008)

[11] A.R. Banerjee, J.A. Jaeger, D.H.: Determination of RNA Structure and Thermodynamics Turner. Biochemistry, 62(1), pp. 255-87. Doi: 10.1146/annurev.bi.62.070193.001351 (1993)

[12] Y. Jin, J.A. Cowan.: DNA Cleavage by Copper-ATCUN Complexes. Factors Influencing Cleavage Mechanism and Linearization of dsDNA. J. Am. Chem. Soc, 127(23), pp. 8408-8415. Doi: 10.1021/ja0503985 (2005)

[13] F. Mancin, P. Scrimin, P. Tecilla, U. Tonellato.: Artificial metallonucleases. Chem. Commun, Vol.0, pp. 2540-2548. Doi: 10.1039/B418164F (2005).

[14] Mudasir., Wijaya, Karna., Tri Wahyuni, Endang.: INTERACTION OF IRON(II) MIXED-LIGAND COMPLEXES WITH DNA: BASE-PAIR SPECIFICITY AND THERMAL DENATURATION STUDIES. Indonesian Journal of Chemistry, 4(3), pp.174-179. https://journal.ugm.ac.id/ijc/article/viewFile/21849/14554 (2004).

[15] Ritacco, Ida., Russo, Nino dan Sicilia, Emilia.: DFT Investigation of the Mechanism og Action of Organoiridium(III) Complexes As Anticancer Agents. Inorg. Chem, 54(22), pp. 
10801-10. Doi:10.1021/acs.inorgchem.5b01832 (2015)

[16] Awang N, and Baba I. Diorganotin(IV) Alkylcyclohexylditiocarbamate Compounds; Synthesis, Characterization and Biological Activities. Sains Malaysiana, 41(8), pp. 977-982. ejournal.ukm.my/jsm (2012)

[17] Aruna K, Drishty S, Anupam M, Madhaya M, Shrmila B, Kannchan K. [99mTc]-labeling of colchine $\left[99 \mathrm{mTc}(\mathrm{CO})_{3}(\mathrm{H} 2 \mathrm{O})_{3}\right]+$. Bioorganic and Medicinal Chem 2006; 14: 793-799.

[18] Bookhari A, Hill JO, and Magee RJ.: Nickel(II) and copper(II) complexes of monoethanol and diethanoldithiocarbamic acid. journal of nuclear Inorganic Chemistry, 36(6), pp. 1253-1257. Doi: 10.1016/0022-1902(74)80060-6 (1974)

[19] Morizzi, J., Hobday, M., and Rix, C.: Gallium(III) organophosphonate adducts with the bidentate amines 2,2'-bipyridyl and 1,10-phenanthroline. Inorganica Chimica Acta, Vol 320, pp. 67-74. Doi.org/10.1016/S0020-1693(01)00471-6 (2001)

[20] Criado, J.J., Lopez, J.A, and Macias, B.: Au(III) complexes of tris-dithiocarbamate derivatives of $\alpha$-amino acids: spectroscopic studies, thermal behaviour and antibacterial activity. Inorganic Chimica Acta, 193(2), pp.229-235. Doi.org/10.1016/S0020-1693(00)80357-6 (1992)

[21] Mjos KD, and Orvig C. Metallodrugs in Medicinal Inorganic Chemistry. Chem.Rev, 114(8), pp. 4540-4563. Doi: 10.1021/cr400460s (2014)

[22] Mudasir., Wijaya, Karna., Tri Wahyuni, Endang.: INTERACTION OF IRON(II) MIXED-LIGAND COMPLEXES WITH DNA: BASE-PAIR SPECIFICITY AND THERMAL DENATURATION STUDIES. Indonesian Journal of Chemistry, 4(3), pp.174-179. https://journal.ugm.ac.id/ijc/article/viewFile/21849/14554 (2004). 

